\title{
SOIL TEST BASED FERTILIZER RECOMMENDATIONS FOR TARGATED YIELDS OF RABI MAIZE (ZEA MAYS) IN VERTISOLS OF TELANGANA STATE
}

\section{G. VEERANNA ${ }^{1} \&$ T. SRIJAYA ${ }^{2}$}

${ }^{1}$ Scientist (Agronomy), Regional Agricultural Research Station, Warangal, India

${ }^{2}$ Scientist (Soil Science and Agricultural Chemistry), AICRP on STCR-Agriculture Research Institute,

Professor Jayashankar Telangana State Agricultural University, Rajendranagar, Hyderabad, India

\section{ABSTRACT}

Investigations were carried out on Response of Maize (Zea mays L.) grain yield (kg/ha) and ratio (kg/kg) to the nutrients applications in Telangana state (Soil Test Crop Response Correlation) during 2008 and 2009 at Regional Agricultural Research Station, Warangal. The experiment were conducted at different sites adjacent to each other on a sandy clay loam soil having a low status in available nitrogen $(272 \mathrm{~kg} / \mathrm{ha})$ in the first year and medium $(323 \mathrm{~kg} \mathrm{~N} / \mathrm{ha})$ in the second year. The soil available phosphorus had a medium status with $60 \mathrm{~kg} \mathrm{P}_{2} \mathrm{O}_{5} / \mathrm{ha}$ in the first year and $50 . \mathrm{kg} \mathrm{P}_{2} \mathrm{O}_{5} / \mathrm{ha}$ in the second year. It was rich in available potassium having 719 and $829 \mathrm{~kg} \mathrm{~K} \mathrm{~K}_{2} \mathrm{O} / \mathrm{ha}$ during the corresponding years. The correlation coefficients between grain yield and nutrients were significant with N P K uptake, their supply through fertilizers and soil $N$ and $K$ but not $P$ in the two years. The basic data to produce one quintal of grain was estimated at $1.86 \mathrm{~kg} \mathrm{N;1.23}$ $\mathrm{kg} P$ and $0.50 \mathrm{~kg} \mathrm{~K}$ in the first year while it was $2.10 \mathrm{~kg} \mathrm{~N}, 1.03 \mathrm{~kg} P$ and $0.54 \mathrm{~kg} \mathrm{~K}$ in the second year. The soil and fertilizer efficiency was almost equal to contribute nitrogen while the soil was more efficient to supply $P$ than the fertilizer and the efficiency of the soil to supply $K$ was less than the fertilizer during two year. The targeted yield equations developed from these basic data were

$$
\begin{array}{cc}
2008 & 2009 \\
F N=6.60 T-0.95 S N & F N=9.40 T-1.32 S N \\
F P=5.54 T-16.07 S P & F P=2.81 T-8.93 S P \\
F K=2.99 T-0.12 S K & F K=3.37 T-0.18 S K
\end{array}
$$

The ready reckoner for targeted yield of 40, 50 and 60 q/ha maize grain yield exhibited considerable variation in the prescription of fertilizers for given soil available nutrients. Hence composite targeted yield equation was developed as mean of two years as per the Project Directorate on All India Coordinated Research projection for Soil Test Crop Response Correlation as.

$$
\begin{aligned}
& F N=7.27 T=1.09 S N \\
& F P=3.84 T-11.63 S P \\
& F K=3.17 T-0.15 S K
\end{aligned}
$$

The ready recokoner for a range of soil test available NPK are furnished. These are to be verified in the farmer's fields on sandy loam soils of Central Telangana Zone for recommendations.

KEYWORDS: Soil Test Approach, Targeted Yield Approach \& Recommendation of Fertilizer in Rabi Maize Crop

Received: Jun 15, 2017; Accepted: Jul 08, 2017; Published: Aug 09, 2017; Paper Id.: IJASRAUG201790 


\section{INTRODUCTION}

The fertilizer requirement of different crops varies due to their differential production potential, ability to draw the mineralized soil nutrients and their additions through the fertilizers. Soil testing is a pre-requisite to know the nutrient imbalance in the soils so as to apply the required amounts of nutrients to correct the imbalance, optimize the crop nutrition for high yield, fetch lucrative profits and maintain the soil health. Therefore fertilizer recommendations for different crops are most often made on the basis of initial soil nutrient status by categorizing them into low, medium and high fertility classes. Such considerations hold good for large variation in soil fertility from field to field. To overcome this limitation, the concept of prescription based fertilizer recommendation for a given soil, crop and environment was proposed through the targeted yield equations developed by Truog (1960). Among the various methods of fertilizer recommendations, the one based on yield targeting is unique because this method not only considers the soil test based fertilizer dose but also the level of yield the farmer can achieve if good agronomic practices are followed to raise the crop. This targeted yield approach is also scientifically sound as the balanced fertilization is ensured not only among the fertilizer nutrients but also the soil available nutrients. Rao and Srivastava (1999) reiterated that the soil test calibration is intended to establish a relationship between the levels of soil nutrients as determined in the laboratory and the crop response to fertilizers observed in the field, permits balanced fertilization of crops. The great complexity in soil test crop response accrues due to a great variety of soils, different climates, crops and management practices. Therefore a well established soil test calibration helps to apply fertilizers in precise amounts and obtain high use efficiency for maximum possible yield in an eco-system. The targeted yield approach based on the soil test crop correlation studies refined by Ramamoorthy et al. (1967) for the first time in India has been successfully adopted through the results obtained from the national net work of All India Coordinated Research Project on Soil Test Crop Response Correlation studies. The basic data needed for formulating fertilizer recommendation based on targeted yield approach are nutrient requirement in $\mathrm{kg} / \mathrm{q}$ produce (grain or other economic produce); the percentage contribution from soil available nutrients and percentage contribution from the fertilizer nutrients.

Targeted yield equations were developed for a number of crops in different parts of Andhra Pradesh (Reddy et al., 1999; Reddy and Ahmed, 2000; Khadke and Ahmed, 2000; Meena et al., 2001; Sreedevi et al., 2001; Chhetri Binoy, 2006 and Swetha, 2006). But, fertilizer recommendations based on this approach for maize in the Central Telangana Zone have not yet been investigated. Maize is a nutrient exhaust crop. It depletes the soil fertility fast. Sridhar et al, (1991) reported that an adequately irrigated crop of maize in the winter season removed $92.9 \mathrm{~kg} \mathrm{~N}, 35.7 \mathrm{~kg} \mathrm{P}$ and $110 \mathrm{~kg} / \mathrm{ha}$. This huge depletion should be replenished through external inputs to sustain the fertility level. Available literature shows that maize respond to heavy dressing of fertilizers up to 180:90:60 kg/ha N P K (Sutaliya and Singh 2005). In another investigation, Kumar et al. (2005) recorded significant improvement in yield by increasing the recommended dose of 120:60:40 kg/ha $\mathrm{N}$ $\mathrm{P} \mathrm{K}$ to the extent of $150 \%$. This result signifies that there is a need to revise the fertilizer schedule from time to time. Farmers in Telangana state seldom follow the recommended dose of 120:60:50 kg/ha. The fertilizer application is indiscriminate.

\section{MATERIALS AND METHODS}

The experiment was conducted at the Regional Agricultural Research Station, Warangal, Telangana State to study Response of Maize (Zea mays L.) grain yield $(\mathrm{kg} / \mathrm{ha})$ and ratio $(\mathrm{kg} / \mathrm{kg})$ to the nutrients applications (Soil Test Crop Response Correlation) during Rabi 2008 and 2009. The experimental site is geographically located at $18^{\circ} 03^{\prime} \mathrm{N}$ latitude and 
$79^{\circ} 22^{\prime}$ E longitude at an altitude of $270 \mathrm{~m}$ above the mean sea level. The experiments were conducted at two different sites in the two years adjacent to each other by about $15 \mathrm{~m}$. Composite soil sample was drawn from 0 to $30 \mathrm{~cm}$ depth from different spots moving randomly in a zig zag manner, in the entire field before the commencement of the experiment. It was analyzed for different physico-chemical properties by adopting standard procedures. The soil was sandy clay loam in texture. It had an alkaline reaction having a pH of 8.10 during 2007 and 8.37 during 2008. There was no problem of salt accumulation in either of the two years. There was a low organic carbon content of 0.47 per cent in the first year and 0.40 per cent in the second year. The fertility status in terms of available nitrogen was different. In the first year, it had a low status with $272.34 \mathrm{~kg} \mathrm{~N} /$ ha while it was medium with $323.67 \mathrm{~kg} \mathrm{~N} /$ ha in the subsequent year. The status of phosphorus was medium with $60 \mathrm{P}_{2} \mathrm{O}_{5} /$ ha in the first year and $50 \mathrm{~kg} \mathrm{P}_{2} \mathrm{O}_{5} /$ ha in the second year. It was very rich in potassium. The available quantity of $\mathrm{K}_{2} \mathrm{O}$ was $719 \mathrm{~kg} /$ ha in the first year and $829 \mathrm{~kg}$ / ha in the second year. The main aim of the Soil Test Crop Response experiment was to generate a set of data points with a wide range of values for each controllable variable of fertilizer NPK at different levels of the uncontrollable soil available NPK fertility variables. To achieve this objective, a fertility gradient experiment was conducted. This was to ensure high heterogeneity between the different fertility gradients and homogeneity within each soil fertility gradient for available soil nutrients, management practices adopted and prevailing climatic conditions. The field was divided into three strips. Each strip was $90 \mathrm{~m}$ long and $16 \mathrm{~m}$ wide separated with $1.5 \mathrm{~m}$ wide alley way all along the length. These strips were designated as $\mathrm{O} X, 1 \mathrm{X}$ and $2 \mathrm{X}$ depending upon the quantity of fertilizers added. Fertilizers were not added in the O X gradient. The standard level of $150 \mathrm{~kg} / \mathrm{N} / \mathrm{ha}$ was applied in $1 \mathrm{X}$ strip. Phosphorus application was calibrated to the critical value based on its fixation capacity following Waugh and Fitts (1966). To supply $10 \mathrm{ppm} \mathrm{P}$, a dose of $22.4 \mathrm{~kg} \mathrm{P}_{2} \mathrm{O}_{5}$ /ha was applied to $1 \mathrm{X}$ strip. The potassium application was calibrated to supply $150 \mathrm{~kg}$ exchangeable $\mathrm{K}_{2} \mathrm{O} / \mathrm{ha}$. Since soil available $\mathrm{K}$ status of the soil was high, a minimum dose of 30 $\mathrm{kg} \mathrm{K} \mathrm{K}_{2} \mathrm{O} /$ ha was applied. The $2 \mathrm{X}$ strip was fertilized with two times the standard dose of nutrients in $1 \mathrm{X}$ gradient. These fertilizer levels are those recommended by the All India Coordinated Research Project on Soil Test Crop Response Correlation Studies.

The exhaust crop of fodder sorghum variety SSG 59-3 was sown during kharif on $1^{\text {st }}$ July, 2007 and $22^{\text {nd }}$ June, 2008. The crop was harvested at flowering stage both years. The fodder yield was recorded from each strip. After the harvest of exhaust crop, the field was ploughed, harrowed and leveled without disturbing the layout demarcation of the three strips developed for the fertility gradient experiment. Each strip was divided into 24 plots measuring 7.0 x $7.8 \mathrm{~m}$. These plots were separated by bunds measuring $45 \mathrm{~cm}$ and alternated by feeder channels of $75 \mathrm{~cm}$ for irrigation

The Treatments were a Combination of Four Levels of Each N, P and K viz.,

$\begin{array}{lcc}\text { Nitrogen (kg N/ha) } & \text { Phosphorus }\left(\mathbf{k g P}_{\mathbf{2}} \mathbf{O}_{5} / \mathbf{h a}\right) & \text { Potassium }\left(\mathbf{k g ~ \mathrm { K } _ { 2 }} \mathbf{O} / \mathbf{h a}\right) \\ \mathrm{N}_{0}-0 & \mathrm{P}_{0}-0 & \mathrm{~K}_{0}-0 \\ \mathrm{~N}_{1}-80 & \mathrm{P}_{1}-40 & \mathrm{~K}_{1}-40 \\ \mathrm{~N}_{2}-160 & \mathrm{P}_{2}-80 & \mathrm{~K}_{2}-80 \\ \mathrm{~N}_{3}-240 & \mathrm{P}_{3}-120 & \mathrm{~K}_{3}-120\end{array}$

A set of 21 treatments comprising the combined levels of NPK and 3 unfertilized controls were randomly allocated in each fertility gradient strip for soil test crop response experiment in accordance with the recommendation by the All India Coordinated Research Project on soil test crop response correlation studies (www.iasi, res.in). The fertilizers 
were applied to the plots as per the treatments. One third of nitrogen and full dose of phosphorus and potassium were applied as a basal dose and remaining nitrogen was applied as top dressing at 40 days after sowing and tasseling stage. The crop was irrigated at the time of sowing and remaining six irrigations were given at 25, 40, 55, 70, 85 and 95 days after sowing

The three basic parameters required to calculate the targeted yield were worked out by following the procedure laid out by Ramamoorthy et al. (1967) as follows.

\section{Nutrient Requirement of N, P and K for Grain Production}

Total uptake of nutrient $(\mathrm{kg})($ Grain + Straw $)$

Kg nutrient $/ \mathrm{q}$ of grain $=$

$$
\text { Grain yield (q) }
$$

\section{Percent Contribution of Nutrient from Soil (CS)}

Total uptake in control plots ( $\mathrm{kg} / \mathrm{ha}) \times 100$

$\%$ Contribution from soil $(\mathrm{CS})$

Soil test values of nutrient in control plots $(\mathrm{kg} / \mathrm{ha})$

\section{Per cent Contribution of Nutrient from Fertilizers (CF)}

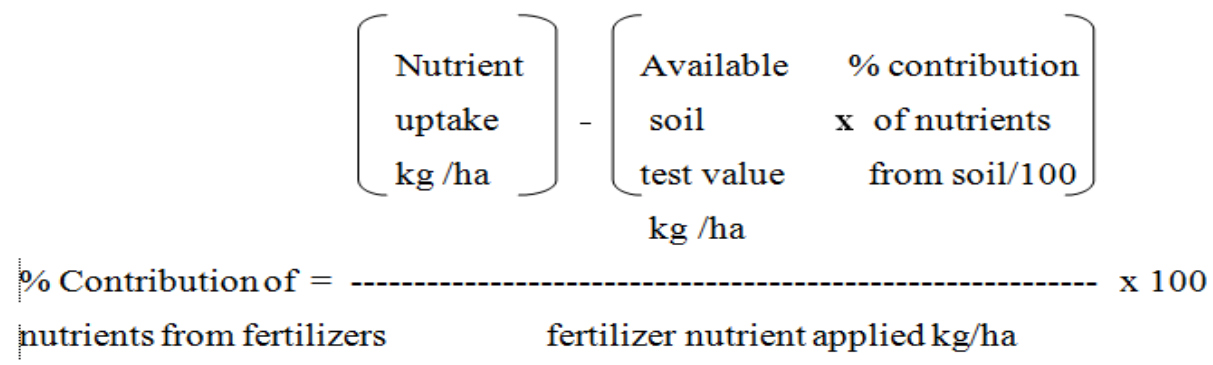

Targeted Yield Equation: It was worked out as follows

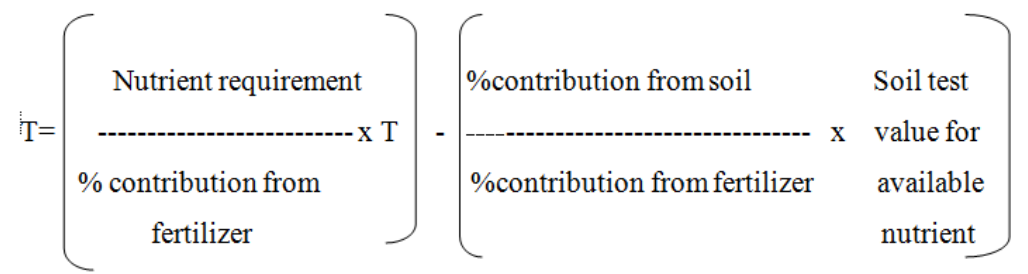

\section{Calculation of Fertilizer Dose}

The basic data are transformed into workable adjustment equation as follows:

Fertilizer dose $=\frac{\text { Nutrient required in } \mathrm{kg} / \mathrm{q} \text { of grain }}{\% \mathrm{CF}} \underset{\% \mathrm{CF}}{\%}$. Soil test value


$=\mathrm{a}$ constant $\mathrm{x}$ yield target $(\mathrm{q} / \mathrm{ha})-\mathrm{b}$ constant $\mathrm{x}$ soil test value $(\mathrm{kg} / \mathrm{ha})$

\section{RESULTS AND DISCUSSIONS}

\section{Basic Data for Targeted Yield Equations}

The basic data on nutrient requirement to produce per $\mathrm{kg}$ of grain and the contribution of $\mathrm{N}$ P K through the soil and fertilizers is presented in Table 1 . The crop required $1.86 \mathrm{~kg} \mathrm{~N}, 1.23 \mathrm{~kg} \mathrm{P}$ and $0.50 \mathrm{~kg} \mathrm{~K} /$ ha to produce 1 quintal of maize grain during the first year. The requirement of these nutrients was $2.10,1.03$ and $0.54 \mathrm{~kg}$ respectively during the second year. The efficiency of soil was estimated to be 26.04 percent for the available nitrogen in the first year and 33.08 per cent in the second year. The contribution of $\mathrm{N}$ through the fertilizer was 19.78 per cent in the first year and 34.68 per cent in second year. The efficiency of the soil supplying $\mathrm{P}$ for the formation of grain was 155.83 per cent in the first year and 143.09 per cent in the second year. The fertilizer contributed 22.20 and 36.68 per cent $\mathrm{P}$ during the two years. The efficiency of the soil to supply potassium was very low. It contributed only 1.70 and 2.46 per cent of its available content during the two years. The relative efficiency of fertilizer supplying this nutrient was relatively less than $\mathrm{P}$ or $\mathrm{N}$ during the two years. Its contribution was 16.73 per cent $\mathrm{K}_{2} \mathrm{O}$ in first year and 16.03 per cent in the second year. The response ratio of the three nutrients viz; N P K to produce per kg grain was 5.58 in the first year and 8.18 in the second year.

The mean values over the second year showed that maize required $1.98 \mathrm{~kg}$ nitrogen $1.13 \mathrm{~kg}$ phosphorus and 0.52 $\mathrm{kg}$ potassium to produce one quintal of grain. The efficiency of nitrogen supplied by the soil and fertilizer was almost equal. The soil supplied 29.56 per cent of the available nitrogen while the contribution of fertilizer was 27.23 per cent. The response to soil nitrogen and fertilizer phosphorus was highly variable. The soil supplied 149.46 per cent $\mathrm{P}$ while the fertilizer was efficient to contribute 29.44 per cent of this nutrient. The soil was relatively less efficient to supply 2.08 per cent potassium unlike the contribution 16.38 per cent by the fertilizer. The mean response ratio was $7.0 \mathrm{~kg}$ grain/ $\mathrm{kg}$ nutrient applied.

\section{Targeted Yield Equation}

The targeted yield equations obtained from basic data were as follows:

2008

$$
\begin{aligned}
& \mathrm{FN}=9.40 \mathrm{~T}-1.32 \mathrm{SN} \\
& \mathrm{FP}=5.54 \mathrm{~T}-16.07 \mathrm{SP} \\
& \mathrm{FK}=2.99 \mathrm{~T}-0.12 \mathrm{SK} \\
& \text { Mean } \\
& \mathrm{FN}=7.27-1.09 \mathrm{SN} \\
& \mathrm{FP}=3.84-11.63 \mathrm{SP} \\
& \mathrm{FK}=3.17-0.15 \mathrm{SK}
\end{aligned}
$$

\section{Ready Reckoner for Soil Test based Fertilizer Recommendations}

The ready reckoner for fertilizer application to attain desired yield level of 40, 50 and $60 \mathrm{q} / \mathrm{ha}$ grain yield of maize for different soil nutrient test values ranging from 125 to $200 \mathrm{~kg} \mathrm{~N}$, phosphors from 8 to 20 and potassium from 500 to 530 
$\mathrm{kg} / \mathrm{ha}$ is furnished in table 2. The level of nitrogen to be applied for different soil test levels within the range of 200 to 340 $\mathrm{kg} \mathrm{N}$, phosphorous from 4 to $16 \mathrm{~kg}$ and potassium from 560 to $640 \mathrm{~kg} / \mathrm{ha}$ estimated from the fertility gradients of the second year are furnished in table 3. A mean estimate over the two years is presented in table 4 to prescribe the quantity of nitrogen, phosphorous and potassium to be applied for targeted yield of 40, 50 and $60 \mathrm{q} / \mathrm{ha}$ over a range of soil test values for the Central Telangana Zone

The concept of fertilizer prescription for desired crop yield based on the soil available nutrients was enunciated by Truog (1960) and later tested in India by Ramamoorthy et al, (1967) based on the premise that the relationship between grain yield and uptake of nutrient follow a linear relationship. The fertilizer requirement can be estimated through the basic data. In the present investigation, the basic data showed that the nutrient requirement of maize was 1.86 and $2.10 \mathrm{~kg} \mathrm{~N}$, 1.23 and $1.03 \mathrm{~kg} \mathrm{P}$ and $0.50 \mathrm{~kg} \mathrm{~K}$ per quintal of grain during 2008 and 2009. The efficiency of the soil to supply the nutrients was 26.03 and $33.08 \% \mathrm{~N}, 155.83$ and $143.09 \% \mathrm{P}$ and 1.70 and $2.46 \% \mathrm{~K}$ during the respective years. The fertilizer was less efficient and supplied $19.78 \% \mathrm{~N}$ compared to $26.04 \%$ by the soil in the first year. But it was equally efficient to contribute $34.68 \% \mathrm{~N}$ as that of $33.08 \%$ through the soil. The fertilizer was less efficient to supply $\mathrm{P}$ than the soil while the reverse was true for potassium.

The results of previous experiments conducted by several investigators indicate that the nutrient requirement needed to produce one quintal of grain varied considerably even for the same crop. The literature showed that the fertilizers were more efficient to supply $\mathrm{N}$ and $\mathrm{K}$ than those available in the soil for grain yield. But the efficiency of soil and fertilizer was highly inconsistent.

Based on the basic data, adjustment equations were generated to predict the nutrient requirement for the targeted yield of 40, 50 and $60 \mathrm{q} / \mathrm{ha}$ maize grain for different soil test ranges created within the experiment during each year. The ready reckoner to prescribe the optimum level of fertilizers depending on the level of nutrients available in the soils was not consistent during the two years. Hence, composite adjustment equation pooling the basis data over the two years was attempted and a ready reckoner for fertilizer prescriptions to target 40, 50 or $60 \mathrm{q} / \mathrm{ha}$ maize grain in the sandy clay loam soils of Central Telangana Zone is furnished. In their exhaustive and critical review Rao and Srivasthava (1999) reported that the adjustment equation for a particular crop or varieties of a crop varied in different seasons or years due to changes in weather. So the soil test calibrations derived from the equations also tended to vary from one year to another. They suggested that possible approach to overcome this problem is to generate a composite adjustment equation by pooling the basic data over the years. The fertilizer recommendations derived from such an approach may be more appropriate and less subjected to year to year fluctuations due to seasonal or weather related changes.

The results on evaluation of fertilizer responses highlighted the usefulness to apply liberal dose of nutrients up to $240 \mathrm{~kg} \mathrm{~N}, 120 \mathrm{~kg} \mathrm{P}_{2} \mathrm{O}_{5}$ and $120 \mathrm{~kg} \mathrm{~K}$ O/ha to realize high grain and fodder yield of maize and profits. The targeted yield equations were more useful to provide a ready reckoner for fertilizer application rates that are conservative and balanced for desired yield goals of 40, 50 or $60 \mathrm{q} /$ ha to suit the highly variable soil available nutrients that vary from field to field and the capacity of the farmer to invest money. The prescription of fertilizer application rates can be extended to the soil available nutrients indicated in the ready reckoner without extrapolation in the sandy clay loam soils of Central Telangana Zone in Telangana state. 


\section{REFERENCES}

1. Chhetri Binoy 2006. Soil test crop response correlation studies in Indian mustard M. Sc (Ag). Thesis submitted to the Acharya $N$ G Ranga Agricultural University, Rajendranagar, and Hyderabad.

2. Khadke KM and Ahmed S Riazuddin 2000.Soil test based fertilizers doses for targeted yield of rainfed castor grown on alfisols. Journal of Oilseeds Research 17(2): 265-270.

3. Meena A, Ahmed S Riazuddin, Reddy K Chandrasekhara and Prasad B R C 2001 Soil test crop response calibration studies on onion (Allium cepa) in Alfisols. Journal of the Indian Society of Soil Science, 49(4) : 709-716.

4. Ramamoorthy B, Narasimhan R L and Dinesh R S 1967 Fertilizer application for specific yield targets of Sonara-64. Indian Farming 5: 43-45.

5. Rao subba A Srivastava sanjay 1999 Experiences on current status of crop responses to fertilizers in different Agro-climatic Zones as learnt from all India coordination research project on soil test crop response correlation. Fertilizer Newa, vol. 44(4), pp. 83-95.

6. Reddy K Chandrasekhar and Ahmed S Riazuddin 1999 Soil test based fertilizer recommendation for groundnut grown in rice fallow ( inceptisols )of Jagtial in Andhra Pradesh. Journal of Oilseeds Research 16 (2) : 257-262.

7. Reedy K Chandrasekhar and Ahmed S Riazuddin 2000 Soil test based fertilizer recommendation for maize growth in inceptisols of Jagtiyal in Andhra Pradesh. Journal of the Indian Society of Soil Science Vol. 48, No.1, pp 84-89.

8. Sreedevi C, Ahmed S Riazudin, Rao B R C Prasad and Reddy K Chandrasekhar 2001 Soil test based fertilizer prescription for maximum yield and profit in sunflower (Helianthus annuus L.) in vertisols of Andhra Pradesh. Journal of Oilseeds Research $18(2): 220-223$.

9. Sutaliya $R$ and Singh R N 2005 Effect of planting time fertility level and phosphate solubilizing bacteria on growth, yield and yield attributes of winter maize (Zea mays) under rice (Oryza sativa) maize cropping system. Indian Journal of Agronomy 50 (3) : 173-175.

10. Swetha $G 2006$ Soil test crop response correlation studies in cabbage. M.Sc (Ag). Thesis submitted to the Acharya N G Ranga Agricultural University, Rajendranagar, and Hyderabad.

11. Troug E 1960 Fifty years of soil testing, transactions of $7^{\text {th }}$ International Congress of Soil Science. Vol. III, Commission IV. Paper No.746-53.

12. Waugh D L and Fitts J W 1966 Soil Test interpretation studies : lafwatag and plotted plant tech. Dull. N. Carol Steaprz exp. Stn. (INTP series) No.3.

\section{APPENDICES}

Table 1: Basic Data on Nutrient Requirement, Soil and Fertilizer Efficiency of Maize

\begin{tabular}{|c|c|c|c|c|c|c|c|c|c|}
\hline \multirow[b]{2}{*}{ Nutrient } & \multicolumn{3}{|c|}{ Rabi 2007-08 } & \multicolumn{3}{|c|}{ Rabi 2008-09 } & \multicolumn{3}{|c|}{ Mean } \\
\hline & $\begin{array}{c}\mathrm{NR} \\
(\mathrm{kg} / \mathrm{q})\end{array}$ & $\begin{array}{c}\text { SE } \\
(\%)\end{array}$ & $\begin{array}{c}\text { FE } \\
(\%)\end{array}$ & $\begin{array}{c}\text { NR } \\
(\mathrm{kg} / \mathrm{q})\end{array}$ & SE $(\%)$ & $\begin{array}{l}\text { FE } \\
(\%)\end{array}$ & $\begin{array}{c}\text { NR } \\
(\mathrm{kg} / \mathrm{q})\end{array}$ & SE $(\%)$ & $\begin{array}{l}\text { FE } \\
(\%)\end{array}$ \\
\hline $\mathbf{N}$ & 1.86 & 26.04 & 19.78 & 2.10 & 33.08 & 34.68 & 1.98 & 29.56 & 27.23 \\
\hline $\mathbf{P}$ & 1.23 & 155.83 & 22.20 & 1.03 & 143.09 & 36.68 & 1.13 & 149.46 & 29.44 \\
\hline $\mathbf{K}$ & 0.50 & 1.70 & 16.73 & 0.54 & 2.46 & 16.03 & 0.52 & 2.08 & 16.38 \\
\hline Response ratio (kg/kg) & \multicolumn{3}{|c|}{5.58} & \multicolumn{3}{|c|}{8.18} & \multicolumn{3}{|c|}{7.00} \\
\hline
\end{tabular}


Table 2: Ready Reckoner of Soil Test Based Fertilizer Doses for Attaining Different Yield Targets of Maize during 2007-08

\begin{tabular}{|c|c|c|c|c|c|c|c|c|c|c|c|}
\hline \multirow{2}{*}{ Soil Nutrients (kg/ha) } & \multicolumn{4}{c|}{ Fertilizer N, P and K Doses (kg/ha) for Different Yield Targets } \\
\cline { 4 - 13 } & & \multicolumn{3}{c|}{ T = 40 q/ha } & \multicolumn{3}{c|}{ T = 50 q/ha } & \multicolumn{3}{|c|}{ T= 60 q/ha } \\
\hline SN & SP & SK & FN & FP & FK & FN & FP & FK & FN & FP & FK \\
\hline 125 & 8 & 500 & 210 & 93 & 60 & 305 & 148 & 90 & 399 & 204 & 119 \\
\hline 130 & 10 & 505 & 204 & 61 & 59 & 298 & 116 & 89 & 392 & 172 & 118 \\
\hline 140 & 12 & 510 & 191 & 29 & 58 & 285 & 84 & 88 & 379 & 140 & 118 \\
\hline 150 & 14 & 515 & 178 & 0 & 58 & 272 & 52 & 88 & 366 & 107 & 118 \\
\hline 160 & 16 & 520 & 165 & & 57 & 259 & 20 & 87 & 353 & 75 & 117 \\
\hline 170 & 18 & 525 & 152 & & 57 & 246 & 0 & 87 & 340 & 43 & 116 \\
\hline 180 & 20 & 530 & 138 & & 56 & 232 & & 86 & 326 & 11 & 226 \\
\hline 190 & & & 125 & & & 219 & & & 313 & & \\
\hline 200 & & & 112 & & & 206 & & & 300 & & \\
\hline
\end{tabular}

Table 3: Ready Reckoner of Soil Test Based Fertilizer Doses for Attaining Different Yield Targets of Maize during 2008-09

\begin{tabular}{|c|c|c|c|c|c|c|c|c|c|c|c|}
\hline \multicolumn{2}{|c|}{ Soil Nutrients (kg/ha) } & \multicolumn{6}{c|}{ Fertilizer n, p and k Doses (kg/ha) for Different Yield Targets } \\
\cline { 4 - 13 } & \multicolumn{2}{|c|}{ T = 40 q/ha } & \multicolumn{3}{c|}{ T = 50 q/ha } & \multicolumn{3}{|c|}{ T= 60 q/ha } \\
\hline SN & SP & SK & FN & FP & FK & FN & FP & FK & FN & FP & FK \\
\hline 200 & 4 & 560 & 52 & 77 & 34 & 113 & 105 & 68 & 174 & 133 & 101 \\
\hline 220 & 6 & 580 & 33 & 59 & 30 & 94 & 87 & 64 & 155 & 115 & 97 \\
\hline 240 & 8 & 600 & 15 & 50 & 27 & 75 & 69 & 60 & 136 & 97 & 94 \\
\hline 260 & 10 & 620 & 0 & 23 & 23 & 56 & 51 & 57 & 117 & 79 & 91 \\
\hline 280 & 12 & 640 & & 5 & 20 & 37 & 33 & 53 & 98 & 61 & 87 \\
\hline 300 & 14 & & & & & 18 & 15 & & 79 & 44 & \\
\hline 320 & 16 & & & & & 0 & 0 & & 60 & & \\
\hline 340 & & & & & & & & & 41 & & \\
\hline
\end{tabular}

Table 4: Ready Reckoner of Soil Test Based Fertilizer Doses for Attaining Different Yield Targets of Maize Pooled Data during 2007 and 2008

\begin{tabular}{|c|c|c|c|c|c|c|c|c|c|c|c|}
\hline \multirow{2}{*}{ Soil Nutrients (kg/ha) } & \multicolumn{3}{c|}{ Fertilizer N, P and K Doses (kg/ha) for Different Yield Targets } \\
\cline { 3 - 13 } & \multicolumn{3}{|c|}{ T = 40 q/ha } & \multicolumn{3}{c|}{ T = 50 q/ha } & \multicolumn{3}{c|}{ T = 60 q/ha } \\
\hline SN & SP & SK & FN & FP & FK & FN & FP & FK & FN & FP & FK \\
\hline 130 & 4 & 500 & 149 & 107 & 52 & 222 & 145 & 84 & 294 & 184 & 115 \\
\hline 150 & 6 & 520 & 127 & 84 & 49 & 200 & 122 & 81 & 272 & 160 & 112 \\
\hline 170 & 8 & 540 & 106 & 61 & 46 & 179 & 99 & 78 & 251 & 138 & 109 \\
\hline 190 & 10 & 560 & 84 & 38 & 43 & 157 & 76 & 75 & 229 & 114 & 106 \\
\hline 210 & 12 & 580 & 62 & 15 & 40 & 135 & 53 & 72 & 207 & 91 & 103 \\
\hline 230 & 14 & 600 & 0 & 0 & 37 & 113 & 30 & 69 & 185 & 68 & 100 \\
\hline 250 & 16 & 620 & & & 34 & 92 & 6 & 66 & 164 & 44 & 97 \\
\hline 270 & 18 & 640 & & & 31 & 70 & 0 & 63 & 142 & 21 & 94 \\
\hline 290 & 20 & & & & & 48 & & & 120 & 0 & \\
\hline 310 & & & & & & 26 & & & 98 & & \\
\hline 330 & & & & & & 4 & & & 76 & & \\
\hline
\end{tabular}

